\title{
Artocarpin isolated from Artocarpus heterophyllus heartwoods alters membrane permeability of Streptococcus mutans
}

\author{
Abdi Wira Septama $^{1 *}$, Pharkphoom Panichayupakaranant ${ }^{2}$ \\ ${ }^{1}$ Faculty of Medicine, Universiti Sultan Zainal Abidin, Jalan Sultan Mahmud 20400, Kuala Terengganu, Terengganu, Malaysia. \\ ${ }^{2}$ Department of Pharmacognosy and Pharmaceutical Botany, Faculty of Pharmaceutical Sciences, Prince of Songkla University, Hat Yai, Songkhla 90112, \\ Thailand.
}

\section{ARTICLE INFO \\ Article history: \\ Received on: 11/03/2018 \\ Accepted on: 10/05/2018 \\ Available online: 29/06/2018}

\section{Key words:}

Artocarpin, A. heterophyllus, antimicrobial, membrane permeability, S. mutans.

\begin{abstract}
Artocarpin was successfully isolated from the heartwoods of $A$. heterophyllus. Objectives: The present study was conducted to determine the antimicrobial activity of artocarpin against cariogenic microbial including Streptococcus mutans, Escherichia coli, and Candida albicans. The activity of artocarpin on alteration of the cell membrane was also investigated. Methods: Standard microdilution method was applied to evaluate its antibacterial activity against tested microorganisms. Time-killing test was then performed to verify its antimicrobial effect. In order to know its effect on membrane permeability, bacteriolysis assay was selected, followed by determining loss of $260 \mathrm{~nm}$ absorbing material using UV-Vis spectrophotometer. Results: Artocarpin exhibited strong antibacterial against $S$. mutans with MIC and $\mathrm{MBC}$ values of 1.95 and $3.91 \mu \mathrm{g} / \mathrm{mL}$, respectively. Time-killing curve showed that artocarpin at $2 \times \mathrm{MIC}(3.9 \mu \mathrm{g} /$ $\mathrm{mL})$ and $4 \times \operatorname{MIC}(7.8 \mu \mathrm{g} / \mathrm{mL})$ inhibited bacterial growth after $4 \mathrm{~h}$ incubation which was comparable to ampicillin as a positive control. Artocarpin $2 \times$ MIC $(3.9 \mu \mathrm{g} / \mathrm{mL})$ and $4 \times \operatorname{MIC}(7.8 \mu \mathrm{g} / \mathrm{mL})$ altered membrane permeability of $S$. mutans after $24 \mathrm{~h}$ exposure and led to release $260 \mathrm{~nm}$ absorbing material as an indicator of membrane cell damage. Conclusion: This finding indicated that artocarpin has high potency as antibacterial compound against $S$. mutans by reducing cell membrane permeability.
\end{abstract}

\section{INTRODUCTION}

Dental caries along with periodontal disease are still a major oral infectious problem worldwide particularly in developed countries (Wang et al., 2017). Many microorganisms, such as Streptococcus mutans, Escherichia coli, and Candida albicans have been reported to contribute to the development of oral health problem (Panyo et al., 2016). Amongst those microorganisms, $S$. mutans is been known as the most cariogenic bacteria which usually cause oral diseases. This bacterium is also the major pathogen associated with the formation of dental plaque biofilms (Choi et al., 2016). Many chemicals and synthetic drugs have been used for the treatment and prevention of the diseases. Chlorhexidine, a broad spectrum antibacterial and antifungal, has been clinically used to reduce the growth of streptococci; however, it is associated

\section{${ }^{*}$ Corresponding Author}

Abdi Wira Septama, Faculty of Medicine, Universiti Sultan Zainal Abidin, Jalan Sultan Mahmud 20400, Kuala Terengganu, Terengganu, Malaysia.E-mail: abdiwiraseptama@gmail.com with some limitations including mouth irritation and unpleasant taste (Ahrari et al., 2015). In addition, the use of antibiotic has also linked with developing of drug resistance (Ghannoum and Rice, 1999). Thus, a search for alternative source of antimicrobial for oral pathogens has been a major concern.

Natural product has been an important source of alternative medicine for the treatment of infectious diseases. Some medicinal plants, such as Robinia pseudoacacia, Emblica officinalis, Ixora megalophylla, and Thymus vulgaris have shown a significant antibacterial effect against cariogenic bacteria, including S. mutans (Patra et al., 2015; Jain et al., 2015; Panyo et al., 2016; Schott et al., 2017). Artocarpus heterophyllus Lam. has been known as one of the ingredients of ancient medicine in some Asian countries (Saxena et al., 2009). It is well known as a source of some secondary metabolites, including flavonoid (Arung et al., 2006). Artocarpin (Fig. 1) is a major compound in the heartwoods of A. heterophyllus (Septama and Panichayupakaranant, 2016a). This compound has demonstrated various biological activities such as anticancer, antioxidant and anticarcinogenic (Sato et 
al., 1996; Yang et al., 2010; Lee et al., 2013). Previously, it has been found that artocarpin could enhance antibacterial activity of some antibiotics in synergistic effect against MRSA (Septama and Panichayupakaranant, 2016b). The study was undertaken to investigate the effect of artocarpin against oral pathogen and to determine its effect towards alteration of membrane cell wall.

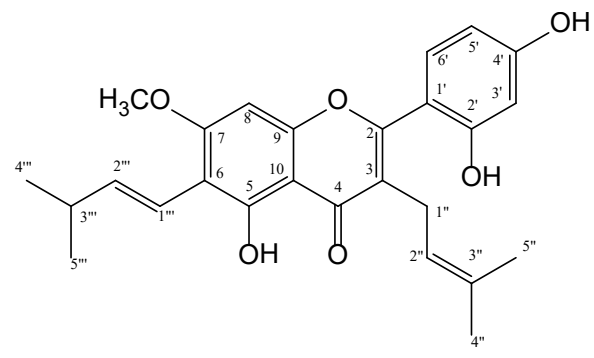

Fig. 1: Chemical structure of artocarpin.

\section{MATERIALS AND METHODS}

\section{Chemicals}

Artocarpin was isolated from ethyl acetate extract of Artocarpus heterophyllus heartwoods as previously describe (Septama and Panichayupakaranant, 2015). Ampicillin and clotrimazole were purchased from Sigma (Sigma-Aldrich, UK). Brain heart infusion (BHI), Sabouraud dextrose broth (SDB) and agar were obtained from the Becton, Dickinson, and Company (Franklin Lakes, NJ).

\section{Bacterial strains}

Streptococcus mutans (DMST 26095), Escherichia coli (ATCC 25922), and Candida albicans (TISTR 5779) were obtained from the Department of Medical Sciences, Ministry of Public Health, Thailand.

\section{Determination of minimum inhibitory concentrations (MICs)}

The microdilution method with slight modification was used to determine minimum inhibitory concentrations (MICs) (NCCLS, 2008). In brief, two-fold dilution of each sample in Brain heart infusion (BHI) (S. mutans and E. coli) or Sabouraud dextrose broth (SDA) (C. albicans) was prepared in 96-wells plate. The cell suspensions were prepared in $0.85 \% \mathrm{NaCl}$, and the turbidity of the suspension was adjusted to the $0.5 \mathrm{McF}$ arland standards, equivalent to $1 \times 10^{8}$ colony-forming unit $(\mathrm{CFU}) / \mathrm{mL}$. This suspension was diluted with normal saline to contain $1 \times$ $10^{6} \mathrm{CFU} / \mathrm{mL}$, and it was then added to each well. The final cell concentration was $5 \times 10^{5} \mathrm{CFU} / \mathrm{mL}$. The plates were incubated at $37^{\circ} \mathrm{C}$ for $24 \mathrm{~h}$. The MIC was considered to be the lowest concentration of the sample that produced suppression of visible growth. The lowest concentration of the sample that inhibits the growth of bacteria in the medium was reflected as the minimum bactericidal concentration (MBC).

\section{Time-kill assay}

Time-killing test was conducted to confirm any bactericidal effect of the sample against tested microbial. This assay was performed eight times $(0,1,2,4,6,8,12$ and $24 \mathrm{~h})$. The microbial suspensions contained $1 \times 10^{6}$ colony-forming unit $(\mathrm{CFU}) / \mathrm{mL}$ was added to a broth containing the mixture of samples to reach the final cell concentration of $5 \times 10^{5} \mathrm{CFU} / \mathrm{mL}$, then incubated at $37^{\circ} \mathrm{C}$. Afterward, aliquots $(50 \mu \mathrm{L})$ of the cultures were removed at eight-time intervals of incubation, and ten-fold serial dilutions were prepared in normal saline. Then, $20 \mu \mathrm{L}$ of each dilution was cultured on Brain heart infusion (BHI) agar. The numbers of viable colonies were then calculated after $24 \mathrm{~h}$ incubation. Dimethyl sulfoxide (DMSO) was used as negative control. The lower limit quantification was $100 \mathrm{CFU} / \mathrm{mL}$ (Hamoud et al., 2014).

\section{Bacteriolysis}

Bacteriolysis assay was carried out as described by Limsuwan (Limsuwan et al., 2012). Briefly, a suspension of an overnight culture of bacteria was prepared in normal saline. Afterward, artocarpin at $1 / 2 \times \mathrm{MIC}, \mathrm{MIC}, 2 \times \mathrm{MIC}$ and $4 \times$ MIC, were mixed with the bacterial suspensions to obtain the final concentration of $5 \times 10^{7}$ colony-forming unit $(\mathrm{CFU}) / \mathrm{mL}$, incubated at $37^{\circ} \mathrm{C}$. Dimethyl sulfoxide (DMSO) was used as a control. Ampicillin was used as positive control. The absorbance of the supernatant at $620 \mathrm{~nm}$ (OD620) was quantified by a UV-Vis spectrophotometer. The measurement of supernatants was carried out eight times $(0,1,2,4,6,8,12$ and $24 \mathrm{~h})$. Reducing of absorbance at $620 \mathrm{~nm}$ was considered as bacteriolysis of tested bacteria. The result was displayed by percentage relative absorbance.

\section{Loss of $260 \mathrm{~nm}$ absorbing material}

The concentrations of released $260 \mathrm{~nm}$ absorbing material were quantified using a UV-Vis spectrophotometer (Devi et al., 2010). The bacterial suspension was prepared from overnight cultures of tested bacteria in normal saline. Artocarpin at $1 / 2 \times \mathrm{MIC}$, MIC, $2 \times \mathrm{MIC}$ and $4 \times \mathrm{MIC}$, were added to the suspension, incubated at $37^{\circ} \mathrm{C}$. The final concentration of bacteria was $5 \times 10^{7}$ colony-forming unit $(\mathrm{CFU}) / \mathrm{mL}$. Dimethyl sulfoxide (DMSO) was used as a control. Ampicillin was used as positive control. Each measurement was performed eight timed $(0,1,2$, $4,6,8,12$ and $24 \mathrm{~h}$ ). The bacterial suspension was then diluted with normal saline $(1: 100)$ and filtered. The optical density at $260 \mathrm{~nm}$ was then quantified using UV-Vis spectrophotometer. The value was considered to be a percentage of the intracellular UV-absorbing material released by the cells.

\section{Statistical analysis}

All experiments were carried out in triplicate. Data was displayed as mean and SD. One-way ANOVA was used for multiple comparisons between these groups, followed by Tukey's test to identify any significant difference at $P<0.01$.

\section{RESULTS}

\section{Minimum inhibitory concentrations (MICs)}

Antimicrobial activity of artocarpin against tested microorganisms was expressed as MIC and MBC values. As shown in Table 1, artocarpin demonstrated strong antibacterial activity against $S$. mutans with $\mathrm{MIC}$ and $\mathrm{MBC}$ values of 1.95 and $3.91 \mu \mathrm{g} / \mathrm{mL}$, respectively. The activity of this compound was also comparable to ampicillin against $S$. mutans (Fig. 2). It indicated that Gram-positive bacteria, S. mutans was susceptive to artocarpin. This bacterium was then used as targeted bacteria 
in order to know the mechanism of action of artocarpin on cell membrane permeability. In contrast, this compound only exhibited moderate activity against Gram-negative, E. coli and yeast, and $C$. albicans (MIC and MBC of 31.25 and $62.5 \mu \mathrm{g} / \mathrm{mL}$ ).

\section{Time-kill assay}

Time-kill curves of $S$. mutans after exposure with artocarpin are presented in Fig. 3. Artocarpin at $2 \times \mathrm{MIC}(3.9 \mu \mathrm{g} /$ $\mathrm{mL})$ and $4 \times$ MIC $(7.8 \mu \mathrm{g} / \mathrm{mL})$ showed strong inhibition effect against $S$. mutans after $2 \mathrm{~h}$. It was comparable to a standard drug, ampicillin as a positive control. This compound at MIC (1.95 $\mu \mathrm{g} / \mathrm{mL}$ ) enabled to inhibit the growth of $S$. mutans within $4 \mathrm{~h}$ exposure, while the sub-MIC $(0.98 \mu \mathrm{g} / \mathrm{mL})$ of artocarpin did not exhibit any inhibition activity after $24 \mathrm{~h}$ incubation.

Table 1: MIC and MBC values of artocarpin, ampicillin, and clotrimazole.

\begin{tabular}{|c|c|c|c|c|c|c|}
\hline & \multicolumn{2}{|c|}{ Artocarpin } & \multicolumn{2}{|c|}{ Ampicillin } & \multicolumn{2}{|c|}{ Clotrimazole } \\
\hline & $\operatorname{MIC}(\mu \mathrm{g} / \mathrm{mL})$ & $\operatorname{MBC}(\mu \mathrm{g} / \mathrm{mL})$ & $\operatorname{MIC}(\mu \mathrm{g} / \mathrm{mL})$ & $\mathrm{MBC}(\mu \mathrm{g} / \mathrm{mL})$ & $\operatorname{MIC}(\mu \mathrm{g} / \mathrm{mL})$ & $\operatorname{MBC}(\mu \mathrm{g} / \mathrm{mL})$ \\
\hline Streptococcus mutans & 1.95 & 3.91 & 0.5 & 0.5 & nd & nd \\
\hline Candida albicans & 31.25 & 62.5 & $n d$ & $n d$ & 0.9 & 1.8 \\
\hline
\end{tabular}

nd: not determined.

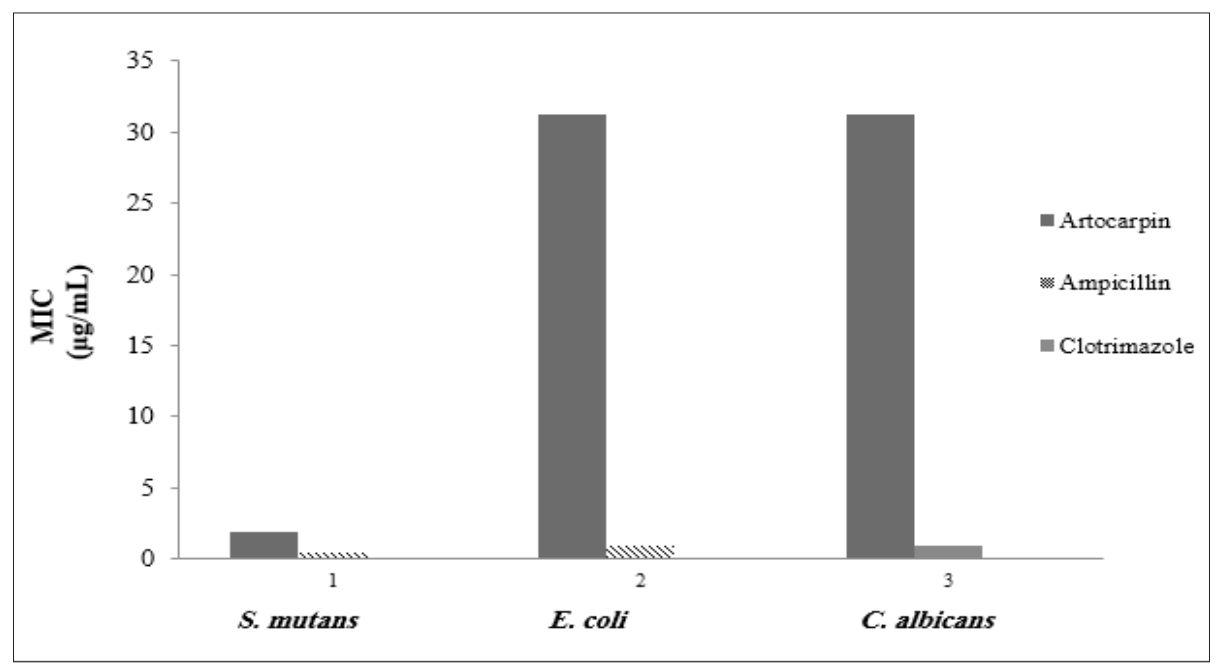

Fig. 2: Inhibitory of artocarpin, ampicillin, and clotrimazole against tested microbial.

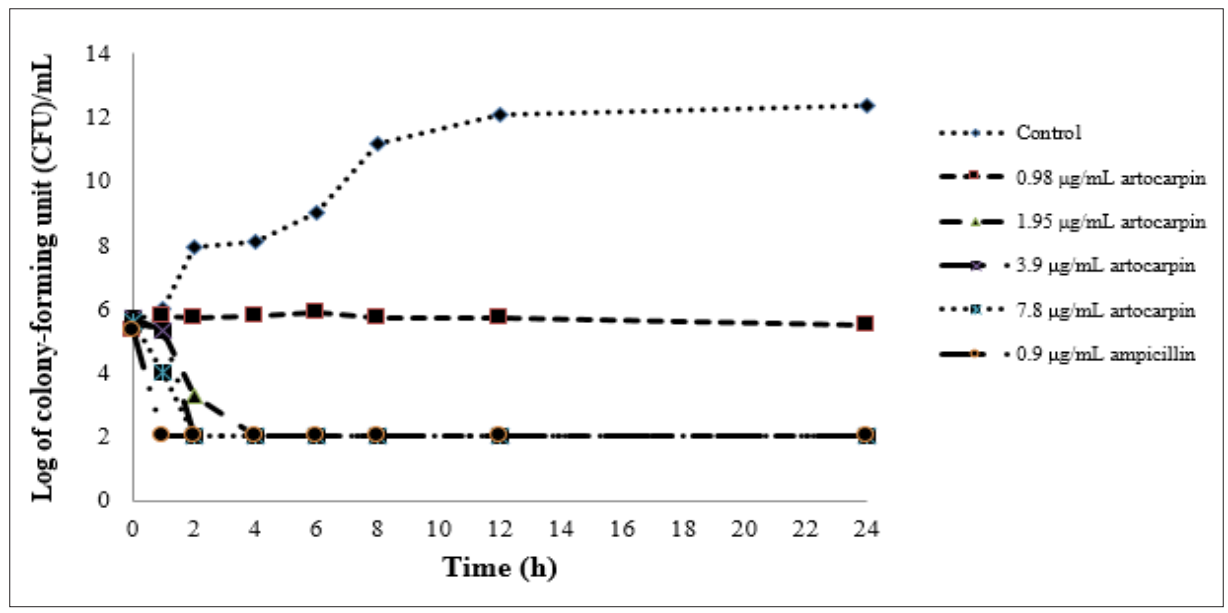

Fig. 3: Time-kill curves of artocarpin and ampicillin against $S$. mutans.

\section{Bacteriolysis}

As shown in Fig 4, exposure with artocarpin at $2 \times$ MIC $(3.9 \mu \mathrm{g} / \mathrm{mL})$ and $4 \times \mathrm{MIC}(7.8 \mu \mathrm{g} / \mathrm{mL})$ caused bacteriolysis effect after $24 \mathrm{~h}$ incubation, which was similar to ampicillin as a positive control. Artocarpin at sub-MIC $(0.98 \mu \mathrm{g} / \mathrm{mL})$ slightly affected cell lysis over $24 \mathrm{~h}$. 


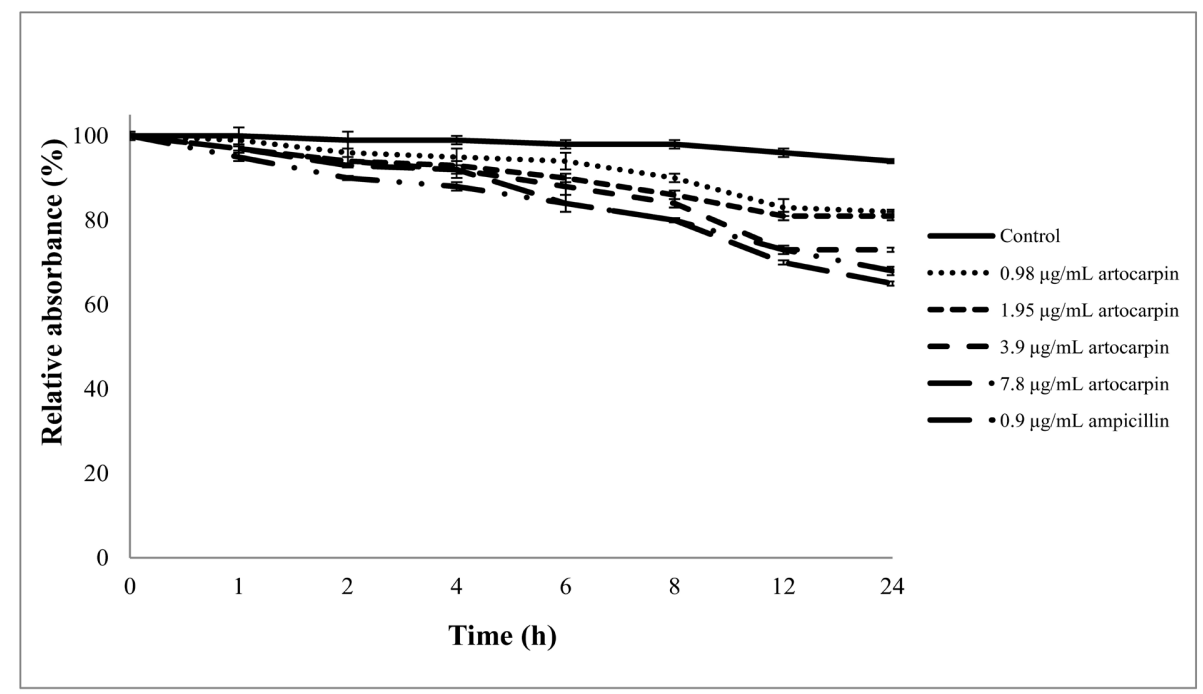

Fig. 4: The bacteriolytic activity of artocarpin and ampicillin against $S$. mutans.

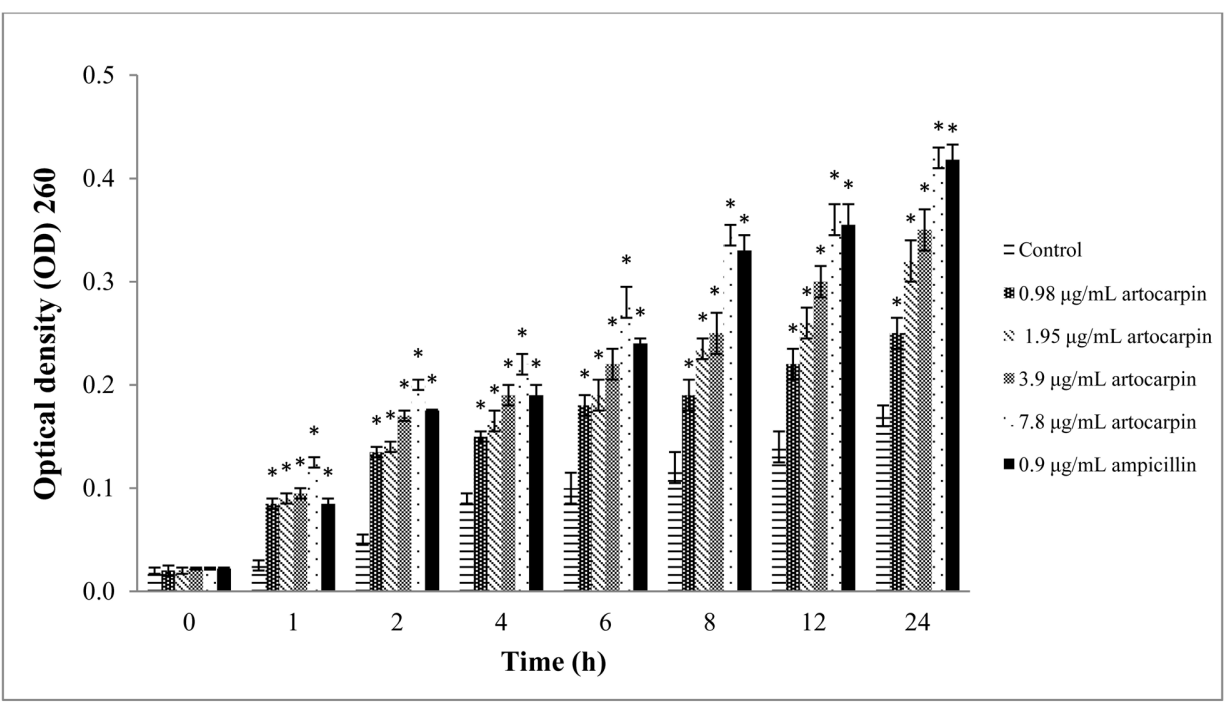

Fig. 5: Optical density (OD) $260 \mathrm{~nm}$ of S. mutans treated with artocarpin. *Significant difference $(P<0.01)$ compared to control.

\section{Loss of $260 \mathrm{~nm}$ absorbing material}

The release of intracellular material from $S$. mutans after treated with artocarpin was monitored as absorbance reading at $260 \mathrm{~nm}$. As presented in Fig. 5, the absorbance of cells treated with artocarpin at $2 \times \operatorname{MIC}(3.9 \mu \mathrm{g} / \mathrm{mL})$ and $4 \times \operatorname{MIC}(7.8 \mu \mathrm{g} / \mathrm{mL})$ were significantly higher than normal cell after $24 \mathrm{~h}$ incubation $(P<0.01)$.

\section{DISCUSSION}

A high failure rate of antibacterial therapy for the treatment of infection caused by cariogenic pathogen has been reported (Sweeney et al., 2004). An appealing approach to overcome this problem is searching potential candidates from medicinal plants which have minimal side effect and high activity. Many compounds isolated from nature have been shown their satisfactory antibacterial activity. Our present study was conducted to evaluate the antibacterial activity of flavonoid isolated from A. heterophyllus namely artocarpin against cariogenic pathogen including $S$. mutans. On the basis of broth microdilution method, artocarpin had strong antibacterial activity against $S$. mutans. Bactericidal activity of this compound was then confirmed using time-kill assay in which artocarpin at supra-MIC enabled to kill $S$. mutans within $4 \mathrm{~h}$ incubation. This finding supports the outcomes of previous studies about the antibacterial activity of artocarpin. According to a previous study, artocarpin showed broad-spectrum antibacterial activity against Gram-positive and Gram-negative bacteria. Moreover, this compound enhanced antibacterial activity of some antibiotics, such as tetracycline, ampicillin, and norfloxacin against MRSA with a synergistic effect when used in combination (Septama and Panichayupakaranant, 2016b). 
Some of the bacterial species, including $S$. mutans are resistant to certain antibiotics due to their attributes, such as low permeability in their cell wall and cytoplasmic (Delcour, 2009). In certain condition, particularly in bacterial resistant, overexpression of efflux pump will reduce accumulation of antibiotics inside the cells (Davin-Regli et al., 2008). Little information is available about the mechanism of antibacterial action of artocarpin. Assessment of its mechanism of action will probably afford starting point for finding and development of new drugs. Membrane permeability has been known as one of the antibacterial targets of the action. Disruption of membrane cell will allow penetration of antibacterial agents across trough bacterial cell and occupy their target of action inside the cell. In this study, we then focused on alteration of membrane cell as a mode of action of the antibacterial compound. Bacteriolysis assay was subjected to determine the effect of artocarpin on membrane cell damage. The test was then continued to confirm the effect of artocarpin on cytoplasmic leakage by measuring the release of absorbing materials at $260 \mathrm{~nm}$. It has been known that membrane integrity is the basis for the control cytoplasmic hemostasis and important for physiological activities in bacteria (Sanchez et al., 2010). This result corresponds well with previous experiment, in which alteration of membrane cell will lead to the release of intracellular material including nucleic acid as an indicator of cell damage.

The finding of this study revealed that artocarpin had strong antibacterial activity against $S$. mutans. This compound also showed a significant effect in altering membrane permeability and finally led to cell lysis. It has been known that flavonoid compound possessed various pharmacological properties including antibacterial. However, the mechanisms of antibacterial actions of flavonoid are still unclear. Their antibacterial action probably involves multiple cellular targets (Kumar and Panday, 2013). The ability of flavonoid to interact with membrane cell as well as their lipophilicity may be also important factors of their biological activity (Tarahovsky et al., 2014). It has been reported that lipophilic flavonoids are able to disturb membrane permeability. Based on previous work, flavonoid from Sophora exigua, named sophoraflavanone $\mathrm{G}$ possessed anti-MRSA by altering its cell membrane (Mun et al., 2014). Naringenin along with some flavonoid including genistein and rutin contributed to altering membrane cell walls (Arora et al., 2000). In addition, flavonoid galangin enabled to induce cytoplasmic membrane damage in $S$. aureus (Cushnie and Lamb, 2011). Disruption of membrane cell walls in hydrophobic and hydrophilic sites can be attributed to this effect which purposes that this flavonoid compound might decrease the permeability of outer layers of membranes. On the other hand, regarding the structure-activity relationship, it can be suggested that substitutions of an isoprenyl group on C-3 and 3-methyl-1butenyl group on C-6 as well as a free hydroxyl group on C-2' are required for antibacterial activity artocarpin. According to a previous study, cudraflavone $\mathrm{C}$ as analogous of artocarpin which has 3 hydroxyl group on C-2', 5 and 7, also showed satisfactory antibacterial activity (Dej-adisai et al., 2014). In addition, Osawa and colleagues reported that substitution of the hydroxyl group on the 7,2' and 4' enhanced antibacterial activity of flavonoid against S. mutans and S. sobrinus (Osawa et al., 1992).

\section{CONCLUSION}

It can be concluded that artocarpin reveal strong antibacterial effect against $S$. mutans by altering its membrane fluidity. These findings provide the important insight about the potency of flavonoid compound named artocarpin to overcome the cariogenic bacterial problem. Nevertheless, further studies are still required to justify the mechanism of antibacterial action of artocarpin.

\section{ACKNOWLEDGMENTS}

Authors wish to thank Prince of Songkla University and the Higher Education Research Promotion and National Research University Project of Thailand, Office of the Higher Education Commission for the research grant.

\section{CONFLICT OF INTEREST}

The authors have declared that there is no conflict of interest.

\section{REFERENCES}

Ahrari F, Eslami N, Rajabi O, Ghasvini K, Barati S. The antimicrobial sensitivity of Streptococcus mutans and Streptococcus sangius to colloidal solutions of different nanoparticles applied as mouthwashes. Dent Res J, 2015; 12(1):44-49.

Arora A, Byrem TM, Nair MG, Starsburg GM. Modulation of Liposomal Membrane Fluidity by Flavonoids and Isoflavonoids. Arch Biochem Biophys, 2000; 373(1):102-109.

Arung ET, Shimizu K, Kondo R. Inhibitory Effect of Artocarpanone from Artocarpus heterophyllus on Melanin Biosynthesis. Biol Pharm Bull, 2006; 29:1966-1969.

Choi O, Cho SK, Kim J, Park CG, Kim J. In vitro antibacterial activity and major bioactive components of Cinnamomum verum essential oils against cariogenic bacteria, Streptococcus mutans and Streptococcus sobrinus. Asian Pac J Trop Biomed, 2016; 6(4):308-314.

Cushnie TPT, Lamb AJ. Recent advances in understanding the antibacterial properties of flavonoids. Int J Antimicrob Ag, 2011; 38:99107.

Davin-Regli A, Bolla JM, James CE, Lavigne JP, Chevalier J, Garnotel E. et al. Membrane Permeability and Regulation of Drug "Influx and Efflux" in Enterobacterial Pathogens. Cur Drug Targets, 2008; 9:750759 .

Dej-adisai S, Meechai I, Puripattanavong J, Kummee S Antityrosinase and antimicrobial activities from Thai medicinal plants. Arch Pharm Res, 2014; 37:473-483.

Delcour AH. Outer membrane permeability and antibiotic resistance. Biochim Biophys Acta, 2009; 1794:808-816.

Devi KP, Nisha SA, Sakthivel R, Pandian SK. Eugenol (an essential oil of clove) acts as an antibacterial agent against Salmonella typhi by disturbing the cellular membrane. J Ethnopharmacol, 2010; 130:107115 .

Ghannoum MA, Rice LB. Antifungal agents: mode of action, mechanisms of resistance, and correlation of these mechanisms with bacterial resistance. Clin Microbiol Rev, 1999; 12:501-517.

Hamoud R, Zimmermann S, Reichling J, Wink M. Synergistic interactions in two-drug and three-drug combinations (thymol, EDTA and vancomycin) against multi drug resistant bacteria including $E$. coli. Phytomedicine, 2014; 21:443-447.

Jain I, Jain P, Bisht D, Sharma A, Srivastava B, Gupta N. Comparative evaluation of antibacterial efficacy of six Indian plants extracts against Streptococcus mutans. J Clin Diagnos Res, 2015; 9(2):ZC50-ZC53.

Kumar S, Panday AK. Chemistry and Biological Activities of Flavonoids: An Overview. Sci World J, 2013; 16.

Lee CW, Ko HH, Lin CC, Chai CY, Chen WT, Yen FL. 
Artocarpin attenuates ultraviolet B-induced skin damage in hairless mice by antioxidant and anti-inflammatory effect. Food Chem Toxicol, 2013; 60:123-129.

Limsuwan S, Kayser O, Voravuthikunchai SP. Antibacterial activity of Rhodomyrtus tomentosa (Aiton) Hassk. leaf extract against clinical Isolates of Streptococcus pyogenes. Evid Based Complement Alternat Med, 2012; 697183-697186.

Mun SH, Joung DK, Kim SB, Park SJ, Seo YS, Gong R. The mechanism of antimicrobial activity of sophoraflavanone B against methicillin-resistant Staphylococcus aureus. Foodborne Pathog Dis, 2014; 3:234-239.

NCCLS. Performance standards for antimicrobial susceptibility testing: Ninth information supplement. NCCLS document M100-S9. 2008. Wayne, PA: National Committee for Clinical Laboratory Standard.

Osawa K, Yasuda H, Maruyama T, Morita H, Takeya K, Itokawa H. Isoflavanones from the heartwood of Swartzia polyphylla and their antibacterial activity against cariogenic bacteria. Chem Pharm Bull, 1992; 40(11):2970-2974.

Panyo J, Matsunami K, Panichayupakaranant P. Bioassayguided isolation and evaluation of antimicrobial compounds from Ixora megalophylla against some oral pathogens. Pharm biol, 2016; 54(9):15221527.

Patra JK, Kim ES, Oh K, Kim HJ, Dhakal R, Kim Y, et al. Bactericidal Effect of Extracts and Metabolites of Robinia pseudoacacia L. on Streptococcus mutans and Porphyromonas gingivalis Causing Dental Plaque and Periodontal Inflammatory Diseases. Molecules, 2015; 20(4):6128-6139.

Sanchez E, Garcia S, Heredia N. Extracts of Edible and Medicinal Plants Damage Membranes of Vibrio cholera. App Environ Microbiol, 2010; 6888-6894.

Sato M, Fujiwara S, Tsuchiya H, Fujii T, Iinuma M, Tosa H. et al. Flavones with antibacterial activity against cariogenic bacteria. J Ethnopharmacol, 1996; 54:171-176.

Saxena A, Bawa AS, Raju PS. Phytochemical changes in fresh-cut jackfruit (Artocarpus heterophyllus L.) bulbs during modified atmosphere storage. Food Chem, 2009; 115:1443-1449.

Schott G, Liesegang S, Gaunitz F, Gleb A, Basche S, Hannig C, et al. The chemical composition of the pharmacologically active Thymus species, its antibacterial activity against Streptococcus mutans and the antiadherent effects of $T$. vulgaris on the bacterial colonization of the in situ pellicle. Fitoterapia, 2017; 121:118-128.

Septama AW, Panichayupakaranant P. Antibacterial assayguided isolation of active compounds from Artocarpus heterophyllus heartwoods. Pharm Biol, 2015; 53:1608-1613.

Septama AW, Panichayupakaranant P. Simultaneous HPLC Analysis of Three Flavonoids in the Extracts of Artocarpus heterophyllus Heartwoods. Nat Pro Sci, 2016a; 22(2):77-81.

Septama AW, Panichayupakaranant P. Synergistic effect of artocarpin on antibacterial activity of some antibiotics against methicillinresistant Staphylococcus aureus, Pseudomonas aeruginosa, and Escherichia coli. Pharm Biol, 2016b; 54(4):686-691.

Sweeney LC, Dave J, Chambers PA, Heritage J. Antibiotic resistance in general dental practice-a cause for concern? J Antimicrob Chemoth, 2004; 53(4):567-576.

Tarahovsky YS, Kim YA, Yagolnik EA, Muzafarov EN. Flavonoid-membrane interactions: Involvement of flavonoid-metal complexes in raft signaling. Biochim Biophys Acta, 2014; 1828(5):12351246.

Wang S, Wu J, Yang H, Liu X, Huang Q, Lu Z. Antibacterial activity and mechanism of $\mathrm{Ag} / \mathrm{ZnO}$ nanocomposite against anaerobic oral pathogen Streptococcus mutans. J Mater Sci: Mater Med, 2017; 28:23-28.

Yang YL, Hou AJ, Zhang HQ, Shen H, Li QS, Zhang CC, et al. Effects of cycloartocarpin A and artocarpin extracted from Fructus Artocarpin Heterophylli on apoptosis of SMMC-7721 and SGC-7901 cells. J Chinese Integr Med, 2010; 8:61-66.

How to cite this article:

Septama AW, Panichayupakaranant P. Artocarpin isolated from Artocarpus heterophyllus heartwoods alters membrane permeability of Streptococcus mutans. J App Pharm Sci, 2018; 8(06): 059-064. 